\title{
Iconography Underpinning Malaysian Portrait Painting
}

\author{
Rosliza Abdul Rahim, Mumtaz Mokhtar, Verly Veto Vermol, Rafeah Legino
}

Faculty of Art and Design Universiti Teknologi MARA, Shah Alam, Selangor, 40450, Malaysia

rosliza258@uitm.edu.my, mumtaz059@uitm.edu.my, verly@uitm.edu.my, rafeahl@uitm.edu.my,

Tel of 1st Author: +60192351516

\begin{abstract}
Malaysian portrait paintings were introduced in the 1930s where local artists started using the subject in their art-making. In art, portraits are generally known as the likeness of a person, especially a face and shoulders, but in fact, there are more ways to define portrait and painting. There is a lack of understanding and interpretation on the subject. Consequently, this study aims to trace the chronology of the development of Malaysian portrait paintings. The stylistic and contextual issues, including its formalistic format, media, themes and styles, and artists, are also examined in this study using a mixed-mode of research method.
\end{abstract}

Keywords: Portraits; Painting; Iconography

eISSN: 2398-4287 ( 2021. The Authors. Published for AMER ABRA cE-Bs by e-International Publishing House, Ltd., UK. This is an open access article under the CC BYNC-ND license (http://creativecommons.org/licenses/by-nc-nd/4.0/). Peer-review under responsibility of AMER (Association of Malaysian Environment-Behaviour Researchers), ABRA (Association of Behavioural Researchers on Asians) and cE-Bs (Centre for Environment-Behaviour Studies), Faculty of Architecture, Planning \& Surveying, Universiti Teknologi MARA, Malaysia.

DOI: https://doi.org/10.21834/ebpj.v6iSI5.2936

\subsection{Introduction to History of Portrait Painting}

Portraiture is an ancient art form dating back to the Ancient Egyptian period, which flourished about 5,000 years ago. During the Late Antiquity and Middle Ages, portraits were mainly created for church manuscripts. Portraits are also related to the history of symbolic representation for religious usage. Before the camera was introduced, portrait paintings were the only way to record the appearance of someone to memorialise the rich and powerful. During this period, the art movement kept evolving even until today. During that time, artists started with the Naturalist, Realism, Impressionism and Expressionism styles before World War I in 1939. However, modern portrait paintings in Malaysia are based on Western styles such as Impressionism, Naturalism and Expressionism in the 1930s-1950s.

\subsection{Problem Statement}

The portrait has long been introduced and applied in Malaysian society. During the initial phase, portrait painting was first established six decades ago with the work of Don Paris in 1922. In 1933, he established and painted the 'Portraits of My wife in Her Wedding'. Yong Mung Seng (impressionism) painted the 'Self Portrait' painting in 1941 and was followed by Catherine Sim's portrait painting entitled 'Salmah' using oils in 1949. After a decade, Hussein Enas (naturalist style) led the Malaysian Art Association (APS) in 1956. After the period of independence, Malaysian local artists such as Zulkifli Buyong still produced portrait paintings such as 'Paper Boat' in the 1960s. In the 1970s, Sulaiman Esa was renowned for his work entitled 'Waiting for Godot'. Amron Omar produced his work (realism) 'Silat II' in 1980, followed by Redza Piyadasa with 'The Haji Family' in 1990. In the year 2000, Ahmad Zaki Anuar (life drawing) created a portrait with charcoal entitled 'figure1'.

Nevertheless, there are still a lack of detailed studies conducted on this topic since it was first introduced nearly six decades ago The need to study the local art history is crucial, as mentioned by D'Zul Haimi (2000) who stated that, "Penulisan Sejarah Seni Visual adalah suatu subjek yang jarang-jarang sekali diperhujahkan secara serius oleh para ilmuan tanah air. Segala bentuk pendefinisian

eISSN: 2398-4287 @ 2021. The Authors. Published for AMER ABRA cE-Bs by e-International Publishing House, Ltd., UK. This is an open access article under the CC BYNC-ND license (http://creativecommons.org/licenses/by-nc-nd/4.0/). Peer-review under responsibility of AMER (Association of Malaysian Environment-Behaviour Researchers), ABRA (Association of Behavioural Researchers on Asians) and cE-Bs (Centre for Environment-Behaviour Studies), Faculty of Architecture, Planning \& Surveying, Universiti Teknologi MARA, Malaysia.

DOI: https://doi.org/10.21834/ebpj.v6iSl5.2936 
semula bidang sejarah seni perlu akur bahawa Sejarah Seni menitikberatkan analisis dan diskusi mengenai imej-imej visual yang terdapat pada semua jangka masa dan tempat. Bidang Sejarah Seni kini memerlukan ilmu pengetahuan yang multi disiplin sifatnya. Kefahaman akan pendekatan-pendekatan baru atau metodologi baru boleh membantu proses menganalisis."

According to Hafizah (2012), the number of books that follow the history and evolution along with the production process as well as the influence of the environment is not up to the standard. This means that along with the long-term importance of visual art, more specific studies shall be done. Mohamed Ali (2012) stated that there is still an insufficiency in the study of historical portrait painting in the past six decades. Even though portrait has long been introduced and applied in the local society, there has been no specific study on portrait painting. It is of paramount importance that research on this particular topic is carried out.

As aforementioned earlier, there is still insufficient primary research highlighting portrait paintings in the Malaysian local art movement. Researches on Malaysian paintings were conducted on several topics. Some of the related titles are: 'Women Figure in Women Artists in Malaysia' by Yuen Chee Ling (2007) from University Sains Malaysia (USM). The Malaysian digital painting was discovered by Mumtaz Moktar (2012). There was another research in art critics by Mohamad Kamal (2016) on content analysis as an important element to understand the Malay culture and society. This research highlighted prominent portrait painters, Mohd. Hussein Enas and statesman Syed Ahmad Jamal. Norhaslinda (2017) graduated his studies with a focus on ornament painting in Malaysia. The Malaysian Islamic Form in Contemporary Islamic Painting, written by Ahmad Rashidi Hassan (2007), stated that no detailed research had been done on Malaysian portrait painting.

Portrait painting plays an important role in the history of modern arts in Malaysia, as well as a role in the national cultural heritage. As stated on 14 February 2009, a portrait painting by Hussein Enas entitled 'Minah' and an artwork by Syed Ahmad Jamal entitled 'Mandi Laut' had been gazetted as part of the national heritage. Declaration of artwork figurative as above seems to be at par with the standard 'quality value' of cultural identity. Likewise, 'Petarungan' figurative martial art by Amron Omar was documented in the book entitled 'Selection of Work Collection Bank Negara Malaysia' and interpreted as the embodiment of cultural identity. Sabapaty (1979) mentioned that portrait paintings become more meaningful if the work is viewed within a context. Similarly, Rohidi (2000) mentioned that bicultural creatures are the products of interaction between biological and cultural factors and cannot be separated from their biological existence. Reading portrait painting in Malaysia could be different from the Western perspective, as it most likely looks into the local elements of customs and traditions, as well as the life of the artist. Based on this, the need for specific analysis and detailed interpretation for local figurative work in Malaysia should be based on the Malaysian cultural context.

'Vision and Idea on Origin and Beginning' (1994) is a book that was written by Piyadasa, Mohamed Ali (2000) and Muliyadi (2007) that discusses Malaysian modern art. Timeline (Jelita Malaysia) by Zakaria (2008) discovered aestheticism in portrait paintings and simple art appreciation from that exhibition. He also mentioned portraits are a treasury of meaning that is very important for researchers because the meaning itself also explore social-politic and cultural issues that can help in revealing the time when the portraits were painted. All the publications above mentioned that portraits are an important subject. Nevertheless, there is still no detailed study on Malaysian portraitists in Malaysia that focuses on the background of the artists' lives. Referring to the local art movement in Malaysia that highlights the lack of documentation, Norazimah (2008) stated that the Timelines Iconic Work in the Permanent Collection of the National Art Gallery consists of portraits, showing that portrait is a crucial subject to highlight. It is demonstrated that every work has its own story that needs to be analysed and put in detail consideration; thus, the young generation can really appreciate their art. The detailed investigation should be conducted via historical research and methodology based on context to uncover the value of national heritage.

Therefore, according to the issues above, there is a need to study portrait painting in order to increase the value of cultural identity in portrait painting in Malaysia.

\subsection{Research aim/objective/question}

This research aims to establish an understanding of Malaysian portrait paintings. To accomplish the aim of the research, the fulfilment of the following objectives will be attempted; Firstly, it intends to trace the chronology of Malaysian portrait paintings from the Modern Era (the 1930s - 1960s) to the Contemporary Era (1970s - 2010s). Second To study the visual language of Malaysian portrait painting based on selected paintings. The third is to analyse the iconographical content of Malaysian portrait painting based on the selected painting.

\subsection{Research Questions}

The corresponding questions of this research are as follows:

1. How and when was portrait painting developed in Malaysia?

2. How artist explored their portrait painting?

3. What are the meanings and why the artist used that treatment?

\subsection{Scope and limitation of the study}

The study will analyse artefacts that suit the concept of portrait painting. Data collection artefact on portrait paintings base on Permanent Collection of National Art Gallery from 1930-2003. The chosen artworks are based on solo exhibitions from three prominent artists exhibited in the National Art Gallery or any local private Gallery. Limitations expected to be encountered during the research include i) limitation of content - The elaboration on grounded theory for this study will be described in this research. 


\subsection{Literature Review}

Portraiture was introduced openly to local artists through the Malaysian Art Association (APS) and individual artists in 1956. In the 1970s, modern art style started garnering appreciation among artists. Pop art treatment was also found in the work of Ibrahim Hussein entitled 'My Father and The Astronaut' in 1970. The year 1971 was the most important moment whereby the National Culture Congress was announced in University Malaya. Obediently, Sulaiman produced his conceptual work entitled 'Man and His World' in 1972. Portrait paintings were impressive in the Pluralist Era, popularised by several artists such as Amron, Omar, Ahmad Zaki Anuar, Bayu Utomo and Jalani Abu Hassan, and are continued by many new artists from today's generation.

There are several studies that are related to the present study. Mumtaz (2009) discussed from the aspect of technical and conceptual issues of digital links to the component of art as usual. This paper discovered some technical issues, including concept of a digital image, the hardware and the software.

Liza Marziana Mohammad Noh (2015) introduced the Formalistic as Analysis Method in Signifying the Malay Culture Symbol in Malaysian Modern Art of Painting which was published in the Mediterranean Journal of Social Science. She used qualitative method and formalistic approach to analyse some figurative art in her research. The latest research paper by Ishak Ramli (2017) highlighted the problem of shariah compliant in visual art and the need of assessment on guideline how to analysis visual art from Islamic perspective. His paper was published in the International E-Journal of Advances in Social Science (IJASOS).

\subsection{Defining art}

The understanding of portrait painting as a concept needs to be perceived in a comprehensive approach. In English, the term art is defined as "something that is created with imagination and skill and that is beautiful or that expresses important ideas or feelings".

'Something' refers to a thing that is unspecified such as an 'idea' that could bring in multiple mediums when making art. Imagination is a creative process from human activities to express ideas. In general, skill refers to the ability of someone to do something. Context of the above definition, it refers to an idea that becomes impactful and attractive as well as a form of communication that could be shared. Beautiful, in general, is used as a label for something attractive or nice because people enjoy looking at it, but here, it refers to an artistic idea that could be stated as anything that could refer to an object or idea related to the process of creating art. Therefore, the word art comes with the term 'create' something via ideas to generate fine and good-looking things or beauty. Skills are the most important element in process of making art. Goguen (2000) focused on who are involved in the creation. He stated that art is something skilfully constructed by an artist. He also mentioned that social context should be one of the important references in defining art.

Sesonske (1965) stressed on audience as part of the component that constitutes the word art. When there is a spectator, the artwork is functional. This situation is more related to communication theory.

Artwork can be elaborated by ingredients of art introduced by Ocvirk and his group subject (2006), including form and content as basic components in visual art. These three items complement each other.

\subsection{Defining painting}

Bell (1999) defined painting as marks on a surface. She assumed that the word mark is considered as images. To her, painting as image and painting as arts has different implications. However, she proposed that images may extend equally to work in either two- or threedimension forms. It is also either mechanically or handmade objects. The most important thing is painting can be in between those two sections and could exist on its own category. Thus, she categorised painting into two:

She concluded that if 'paintings' is about an object; a painting is about practice. In the context of practice, the concept of marks on a surface are implicit more than a stain, smudge or smear impression. It could be a character of something or 'something' that brings a certain meaning. A visual of something which brings certain meaning is considered as a sign (Bell, 1999). The role of a sign is giving a representation of images classified as pictorial representation and behind the picture it consists certain meaning. Technically, marks are not only by using brush, pencil or graphic tools but can be effects of vehicles, environmental causes and so on. The concept of surface is about any visible or solid expanse which could stop the way of light (Bell, 1999). Once the surface was marked, it becomes an essential part of that painting. Besides that, the history of image making, the philosophy of image, the concept and the technicality of painting, there are many other considerations regarding painting. These other aspects will provide keywords of painting that will inject deeper understanding.

\subsection{Types of portrait paintings}

Common types of paintings are differentiated based on the subject matter, medium and surface used for painting, style adopted for painting, subject of painting also could be the theme used by the artist. In the context of fine artwork, paintings can be classified on the basis of their subject or object which is being displayed. Some of the common types of portrait paintings are -religious portraiture, individual portrait, historical, vanity, self-portrait, nude, allegorical, and portraits according to pose, size and length of portrait.

\subsection{Defining portrait}

Portrait is usually associated with a painting, drawing or photograph of a person. Generally, the public will refer portrait to the person's face. Literally, in English, the term portrait is considered as "a figure drawn or painted" or "to paint, depict" (portray). A portrait is a portrayal of a person, usually showing the person's face (but not always). Portrait also carries the meaning "any likeness of a person, in any medium". On the other hand, portrait can also be understood as a "word picture of a person's appearance and character". According to Oxford's Advanced Learner Dictionary (2002) portraits can be understood as "a representation" of any likeness of a person in any medium. The keywords associated with the term portrait are "to portray", "any likeness", "any medium", "a figure", "person's face", 
"representation" and "character". All those keywords will enhance the understanding of portrait paintings. There are categories of portrait painting in Malaysia. First is portrait according to a figure drawn (imitation), second is comes from the word 'portray' the likeness, third is portrait define as medium and portrait define according to portray a 'conceptual representation' and symbolic representation (nonpresentable through likeness).

\subsection{Research Methodology}

This Qualitative research will be based on the discipline of art history within the evolution and development of the philosophy tradition of Western civilisation. This Historical study based on Anne D'Alleva (2010): It contains Formalistic Analysis and Contextual analysis. Theory from Erwin Panofsky and Giorgio Vasari will be used in order to analyse paintings. Vasari interpretation involves the unfolding of an artist's biography to be interrelated with the various stylistic developments. The main aims of his approach are 'connoisseurship and humanism', stressing on the importance of looking at works with an artist's eye and of documentary evidences to produce his biographical method. He proposed three stages of historical time, childhood, youth and maturity which produced a chief model of cycle of ages. Published materials, artefacts and primary data were gained through many approaches. These include review of literature, observation and interviews.

\section{Erwin Panofsky's Theory of Meaning in Art}

Based on Descriptions by Shatford (1986) and Jörgensen (2003)

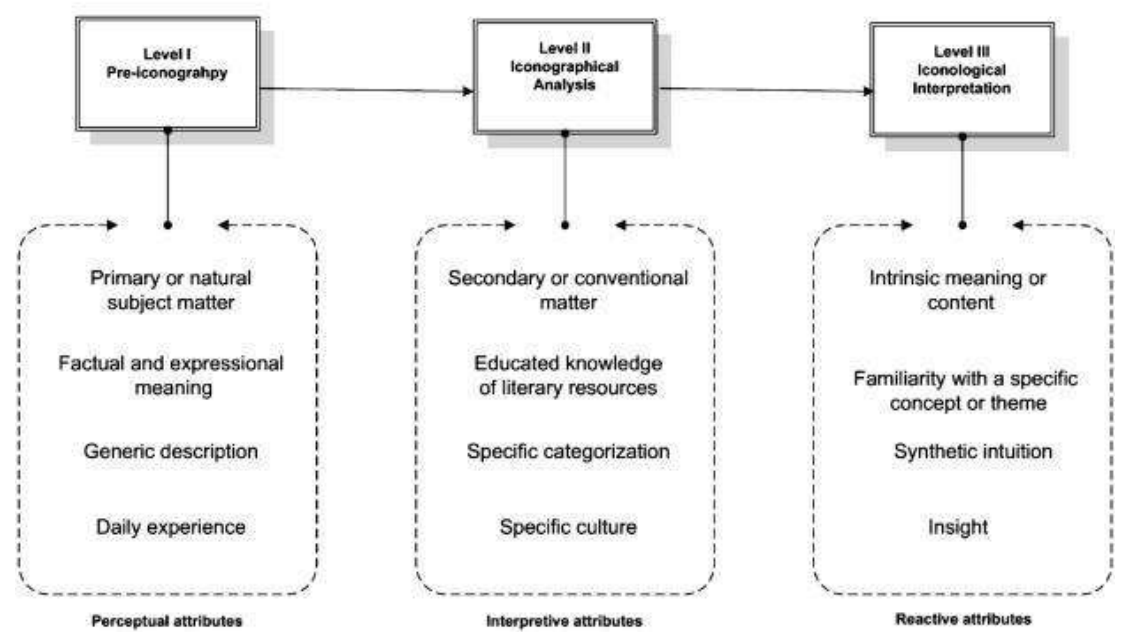

Fig. 1: Erwin Panofsky's Theory of Meaning in Art

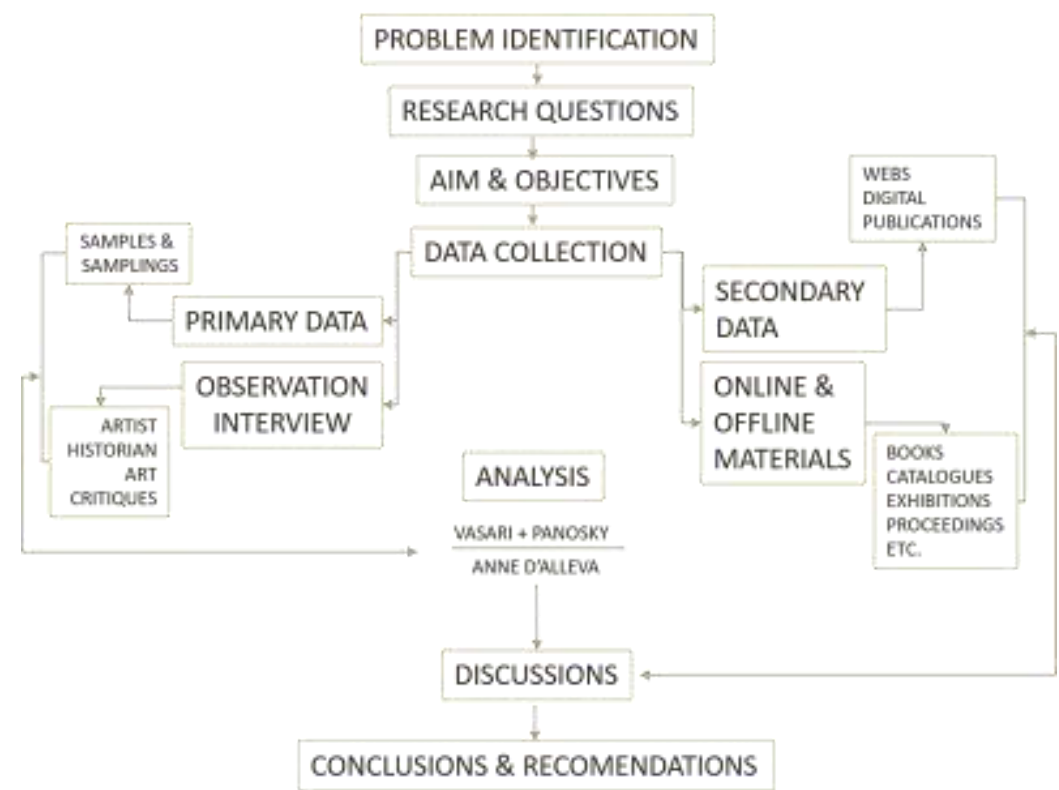

Fig. 2: Research Design 


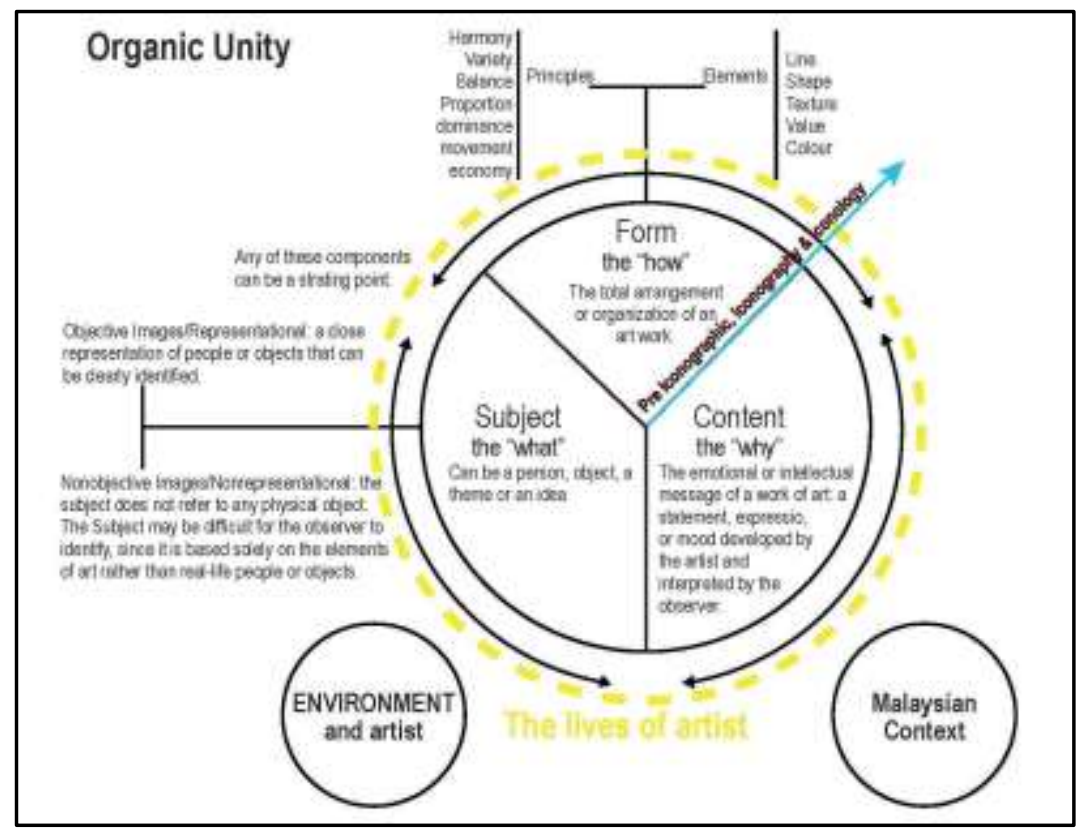

Fig. 3: Conceptual framework

\subsection{Findings}

The expected findings of the study are summarised into the following; this study will inspire local artists to explore more possibilities in terms of portrait painting and styles. Provide the benefits knowledge of portrait painting for the art critics, student academicians, historians and related disciplines. Will provide a chronology of the time frame of portrait paintings in Malaysia. Discover the development of Malaysian portrait painting and also support the National Industry Creative initiatives (TN50 and DIK6).

\subsection{Discussion}

Portrait painting, in brief, a portrait is a noun referring to an image or picture. Portrait in the verb is the way of production and in adjective is an outcome product such as painting, drawing, printmaking and photography.

Portrait painting is a convergence of two words - portrait and painting. Portrait can be understood as the human figure, which is derived from the real subject of the human body. Nevertheless, conceptually, the portrait can be understood as a representation of anything that could be a sign that portrays a person's character or appearance. At the same time, painting is a type of visual artwork which contains several elements and principles of art. The organisation of elements and principles carries certain meanings and messages. Consequently, the perspective of looking at portrait painting should combine both the term of the portrait as well as the concept of painting.

\subsection{Different ways of seeing}

It is a juxtaposition of two portraits of the same man Maori Chief, Tupa Kupa. One image is a portrait by an English artist, the other is a self-portrait by the chief himself. According to Niranjan (1999), Fred, Chistin, Richard (2001) highlight in writing issues of how can scholar understand culture unlike their own could be limited by their distance from the thought pattern of the culture they study and by the obstruction to understanding their own though pattern raise-the statement, presupposition and prejudice peculiar to their own culture (may reconstruct a distorted picture of the past because of culture-bound blindness). The Illustration portraits of Maori chief Te Pehi Kupe English Artist; John Sylvester and Te Pehi Kupe (1826) were shared in The Childhood of Man by Leo Frobenius in New York, 1909.

\subsection{Conclusion}

Portraits paintings have long existed in Malaysia, but there are not many studies on this subject, thus a lack of understanding on this subject for others to make references. There are various styles, and some of the controversial portrait works have emerged lately and caused disruptions to local citizens whether they should be accepted or not while the country is moving towards a developed country status. Portrait painting in Malaysia is not highlighted in previous studies or publications. As a result, the past history, especially the story behind the painting, is not exposed or revealed and lack critical discussion. This concept paper introduces the idea of the research study. It described the aim and its objectives which are related to the problem stated. It also presented factors of the background that 
placed this topic in the particular context of the study. This investigation is believed as a worthwhile study as it contributes to the advancement of information to the area of study. All research questions in this chapter are the guidelines for the progression of research.

\section{Acknowledgements}

The authors would like to acknowledge the Research Management Center (RMC), Universiti Teknologi MARA, for funding under the grants of the 600-IRMI/MYRA 5/3/REI (002/2018) for this publication.

\section{References}

Adam, J. and Bonhomme, M. (2003), L'argumentation publicitaire. Rhétorique de l'eloge et de la persuasion, Nathan Université, Paris.

Ahmadrashidi, H. (2013), Islamic Art in the Malay World, UiTM Press, Shah Alam.

Bell, J. (1999), Representation and Modern Art, Thames and Hudson, London.

Cömert, B. (1980), Mitoloji ve ikonografi, Meteksan Ltd. Co. Printing, Ankara.

D'zul, H. (2008), Pelukis dan Peristiwa. Kuala Lumpur, KL: R. A. Fine Art Kuala Lumpur.

Danto, A. C. (n. d.), What Art Is, Yale University Press, USA.

Dictionary.com. (2018), Portrait. [online] Available at: http://www.dictionary.com/browse/portrait

Esaak, S. (2018, March 23), What is the definition of 'Medium' in art? Available at: https://www.thoughtco.com/

First ASEAN Symposium on Aesthetic. (n. d.), Proceeding of Symposium, National Art Gallery, Kuala Lumpur.

Gair, A. (1993), The Complete Step-By-Step Portrait Painting Course, Reed International Book Ltd, New York.

Gaunt, W. (1967), A Companion to Painting, Thames and Hudson, London.

Günay, V. D. (2008), "Görsel okuryazarlık ve imgenin anlamlandırılması", The Refereed Journal of the Faculty of the Fine Arts, Vol. 1, pp. 1-29.

Hasnol, J. S. (2008), In Between the Line, Universiti Sains Malaysia, Kuala Lumpur.

Hobbs, J. A. (1985), Art in Context, Harcourt Brace Jovanovich Publishers, United State.

Kendall, P. M. (n. d.), Biography Narrative Centre, Available at: http://www.britannica.com

Mohammad Ali, A. R. (2012), Modern Malaysia Art: Manifestation of Malay Form and Content, Universiti Teknologi MARA, Shah Alam.

Muliyadi, M. (2007), Mordern Malaysia Art, Utusan Publication \& Distributors Sdn Bhd, Selangor.

National Art Gallery. (2000), Review of Malaysia Modern Art, National Art Gallery Kuala Lumpur.

National Art Gallery. (2008), Susur Masa, National Art Gallery, Kuala Lumpur.

Ocvirck, Stinson, Wigg, Bone and Cayton. (2006), Art Fundamentals: Theory and Practices (10th Ed.), McGraw Hill, Boston.

Oxford Advanced Learner's Dictionary of Current English. (2000), Word, Oxford University Press, New York.

Sabapathy, T. K. (1978), A Detail Discussion of Artist, Exhibition and Issues, Archipelago Publishers, Kuala Lumpur, pp. 13-30.

Sabapaty, T. K. and Piyadasa, R. (1983), Modern Artists of Malaysia, Penerbit Dewan Bahasa dan Pustaka, Kuala Lumpur.

Sesonke, A. (1965), Aesthetic Theory from Plato to Tolstoy.

Simpson, I. (Ed.). (2001), The Complete Painting Course, Greenwich Editions, London.

Syed Ahmad, J. (2007), Crafts and the Visual Arts, Miller, Kuala Lumpur.

Ter-Grigogyan, J. (n. d.), The Analysis and Interpretation of Greeting and Smiling Gestures in Communication, Armenian State Pedagogical University.

Vocabulary.com. (n. d.), Portrait, Available at: https://www.vocabulary.com/

Woodall, J. (1997), Facing the Subject, Manchester University Press Manchester.

Zakaria, A. (2012), Teori-Teori Seni, Univison Press Sdn Bhd, Malaysia 